\title{
Discovering the Value of Liberty in Intellectual Property Adjudication: A Methodological Critique of the Reasoning in Discovery Ltd v Liberty Group Ltd 20204 SA 160 (GJ)
}

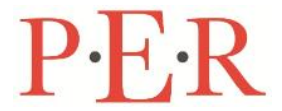

Pioneer in peer-reviewed, open access online law publications

Authors

Richard M Shay

Ndivhuwo I Moleya

Affiliation

University of South Africa Attorney of the High Court of South Africa

Email

shayrm@unisa.ac.za

ndvhwishmel@gmail.com

Date Submission

\section{April 2021}

Date Revised

\section{August 2021}

Date Accepted

10 August 2021

Date published

14 September 2021

Editor: Prof C Rautenbach

How to cite this article

Shay RM, Moleya NI "Discovering the Value of Liberty in Intellectual Property Adjudication: A Methodological Critique of the Reasoning in Discovery Ltd $v$ Liberty Group Ltd 20204 SA 160 (GJ)" PER / PELJ 2021(24) - DOI http://dx.doi.org/10.17159/17273781/2021/v24i0a10703

\section{Copyright}

\begin{abstract}
This article discusses the recent decision in Discovery Ltd $v$ Liberty Group Ltd 20204 SA 160 (GJ), which concerned a claim of trade mark infringement in terms of sections 34(1)(a) and 34(1(c) of the Trade Marks Act 194 of 1993 and unlawful competition on a developed reading of the common law. This article argues that the court arrived at the correct conclusion by the incorrect means and failed to adequately construe the array of constitutional interests and considerations that pertained to the matter on the facts. Further, the lack of clarity on the appropriate constitutional port of entry for the judicial enquiry unnecessarily leaves future courts guessing regarding the correct methodology to employ in cases where intellectual property rights are asserted in opposition to constitutional rights and interests. It is argued that the transformative impetus of section 39(2) of the Constitution of the Republic of South Africa, 1996, as well as numerous substantive constitutional provisions are undermined when courts neglect to anchor judicial reasoning in the constitutional context and merely apply a constitutional veneer to whatever outcome has already been reached. Accordingly, we argue that courts are under a general obligation to root all adjudication in constitutional norms and method, which, we submit, secures a thicker concept of the value of liberty than has been produced in this decision.
\end{abstract}

\section{Keywords}

Intellectual property; trade marks; unlawful competition; constitutional methodology; constitutional interpretation; transformative adjudication. 


\title{
1 Introduction
}

\begin{abstract}
Any practical legal argument, no matter how detailed and limited, assumes the kind of abstract foundation jurisprudence offers, and when rival foundations compete, a legal argument assumes one and rejects the other. So any judge's opinion is itself a piece of legal philosophy, even when the philosophy is hidden and the visible argument is dominated by citation and lists of facts. ${ }^{1}$
\end{abstract}

The interface between intellectual property rights and constitutional rights usually ignites some perplexing legal questions. This arguably owes to the differing normative standards applicable in the assessment of these sets of rights. ${ }^{2}$ Problems arise when courts overlook countervailing interests that may be protectable under the constitutional rights framework when resolving what appear to be intellectual property rights disputes. Potentially protectable competing constitutional interests are pitted against intellectual property rights without being formally recognised and accorded the necessary weight. This ultimately results in an imbalance which presumptively privileges intellectual property rights over such competing interests. Discovery Ltd v Liberty Group Ltd is one such decision. ${ }^{3}$

Ostensibly, the Discovery case raised ordinary questions of the infringement of trade mark rights with an additional aspect of unlawful competition. On careful examination, however, one discerns that the case also raised underlying constitutional questions of momentous import. The decision underlines the obliviousness of our courts to constitutional paradigms and methodologies when resolving seemingly standard intellectual property law disputes. Although we have no qualms about the outcome of the case, and indeed we generally agree that the correct outcome was reached in this decision, the methodological approach adopted in arriving at the outcome is unattractive. The court sidelined significant constitutional questions regarding the applicability of competitors' commercial speech and other provisions supporting the public interest. The argument developed here is that the court should have formally identified Liberty's use (and assess the impact of competing rights on it) and consequently located it on the

Richard M Shay. LLB LLM (US). Senior Lecturer in the Department of Mercantile Law, College of Law, UNISA, South Africa. Email: shayrm@unisa.ac.za. ORCID: https://orcid.org/0000-0002-9437-9802. I should like to thank Elsabé van der Sijde, Roshana Kelbrick, and the participants of the UNISA IPL Working Paper Series held during February 2021. The usual disclaimers apply.

** $\quad$ Ndivhuwo Ishmel Moleya. LLB (Univen) LLM (UNISA). Attorney of the High Court of South Africa. Email: ndvhwishmel@gmail.com. ORCID: https://orcid.org/0000-00030790-8540.

Dworkin Law's Empire 90.

Du Bois 2012 SA Merc LJ 178.

Discovery Ltd v Liberty Group Ltd 20204 SA 160 (GJ) (hereinafter Discovery). 
constitutional normative framework, as opposed to simply categorising it as non-trade mark use. A similar approach (which formally recognises Liberty's use as a protectable interest) should have been adopted when resolving the competition law claim. ${ }^{4}$ The court's approach on the trade mark dispute arguably veered off the path charted by the Constitutional Court in Laugh It Off and undermines the constitutional injunction, clearly enunciated in Investigating Directorate: Serious Economic Offences $v$ Hyundai Motor Distributors (Pty) Ltd In re: Hyundai Motor Distributors (Pty) Ltd v Smit ${ }^{5}$ and Pharmaceutical Manufacturers Association of South Africa: In re Ex Parte President of the Republic of South Africa, ${ }^{6}$ to interpret all law in line with the Constitution. ${ }^{7}$ The court's approach on the competition claim also fails to honour the adjudicative approach pronounced in Phumelela Gaming and Leisure Ltd v Gründlingh. ${ }^{8}$

\section{Discovering liberty in South African law}

\subsection{The facts of the case}

Discovery (Pty) Ltd and others applied for a prohibitory interdict against Liberty Group Ltd regarding the alleged infringement of the "DISCOVERY" and "VITALITY" trade marks and engaging in unlawful competition. ${ }^{9}$ The two trade marks were owned by Discovery (Pty) Ltd but were being used by Discovery Life Ltd and Discovery Vitality (Pty) Ltd. ${ }^{10}$ Discovery Life Ltd offered life insurance and other related services while Discovery Vitality (Pty) Ltd's primary business comprised the Vitality Wellness and rewards programme. The programme allowed a member of the Discovery Group to join by paying a monthly membership fee and members who led a healthy lifestyle earned points - the more points a member earned, the higher their Vitality status. ${ }^{11}$ Liberty's business included the sale of life insurance and

$4 \quad$ Liberty's interests, along with those of the Vitality members, should have featured in the weighing-up process when determining the issue of wrongfulness.

$5 \quad$ Investigating Directorate: Serious Economic Offences v Hyundai Motor Distributors (Pty) Ltd In re: Hyundai Motor Distributors (Pty) Ltd v Smit 20011 SA 545 (CC) para 21 (hereinafter Hyundai).

6 Pharmaceutical Manufacturers Association of South Africa: In re Ex Parte President of the Republic of South Africa 20002 SA 674 (CC).

7 Laugh It Off Promotions CC v South African Breweries International (Finance) BV t/a Sabmark International 20061 SA 144 (CC) (hereinafter Laugh It Off Concourt).

$8 \quad$ Phumelela Gaming and Leisure Limited v Gründlingh 20076 SA 350 (CC) (hereinafter Phumelela).

Discovery para 9.

10 Discovery Life Ltd and Discovery Vitality (Pty) Ltd are permitted users in terms of $s$ 38(2) of the Trade Marks Act 194 of 1993 (hereinafter Trade Marks Act).

11 Discovery Vitality members start out with a Blue status and can progress through the ranks to Bronze, Silver, Gold, and Diamond status. 
related products and was in direct competition with Discovery Life. It operated an insurance policy called Liberty Lifestyle Protector Plan that had an additional feature called the Wellness Bonus. Customers who took out the policy could elect to disclose an existing membership of an external wellness programme and, if the programme was recognised by Liberty, the policyholder would be refunded a portion of the premiums. The repayment of a portion of the premiums was dependent on a Liberty Wellness Score, which was determined by the status of the policyholder on the recognised external Wellness programme. ${ }^{12}$ As Liberty did not operate a Wellness programme, it recognised two external wellness programmes, namely Discovery Vitality and Momentum Multiply.

The basis of the applicants' contention was that Liberty unlawfully linked its insurance policy, through the Wellness Bonus, to Discovery's Vitality Wellness programme and that this constituted an infringement of the "VITALITY" and "DISCOVERY" trade marks. They also contended that the use constituted unlawful competition as Liberty rode on the reputation and "back-office" of the Vitality Wellness programme. ${ }^{13}$ The alleged infringement of the trade marks centered on the use of two documents. The first document was an online quotation generated by an insurance broker for a customer, with an attachment. Although the quotation document did not bear the contested trade marks, the attachment did. The second was an instruction document issued to existing policy holders. ${ }^{14}$ The quotation document was generated through a Liberty system and on a Liberty banner. ${ }^{15}$ Although the system was accessible only to brokers, it recognised Wellness programmes offered by Discovery, which resulted in the "VITALITY" trade mark being reproduced on the system-generated document. ${ }^{16}$ The instruction document made reference to the Discovery trade marks and was used by customers to upload the status of their external Wellness programmes onto the Liberty system. ${ }^{17}$ The document contained a disclosure of the fact that both "DISCOVERY" and "VITALITY"

12 If a policy holder is a member of the Vitality programme and has a Blue status, the member will have a lower Liberty Wellness Score and will receive a lower percentage of premiums back than another Liberty Plan policyholder who is a Diamond status member of the Vitality programme.

13 The "back office" referred to by the applicants includes all the behind-the-scenes operations, information and know-how, and the personnel necessary to run the scheme, that goes into maintaining and developing the Vitality programme.

14 Discovery para 12.

15 Discovery para 16.

16 Discovery para 16.

17 An embedded hyperlink in the instruction document directs users to either Discovery Vitality or Momentum Multiply websites. 
are registered trade marks for Discovery (Pty) Ltd and that "MULTIPLY" is a registered trade mark for Momentum Multiply. ${ }^{18}$

\subsection{The court's approach to trade mark infringement under sections 34(1)(a) and 34(1)(c) of the Trade Marks Act}

The applicants argued that Liberty's use of the "VITALITY" and "DISCOVERY" trade marks constituted an infringement of the trade marks in terms of sections 34(1)(a) and 34(1)(c) of the Trade Marks Act. ${ }^{19}$ Relying on Verimark (Pty) Ltd $v$ Bayerische Motoren Werke AktienGesellschaft, ${ }^{20}$ the court pointed out that in order to constitute an infringement under section 34(1)(a), Liberty's conduct must constitute "trade mark use". ${ }^{21}$ In that case, the Supreme Court of Appeal (SCA) stated that "a trade mark serves as a badge of origin and that trade mark law does not give copyright-like protection.".22 It warned against an interpretation of section 34(1)(a) which affords "greater protection than that which is necessary for attaining the purpose of a trade mark registration", namely "protecting the mark as a badge of origin". ${ }^{23}$ In line with the pronouncements of the SCA, the court acknowledged that the scope of protection afforded by section 34(1)(a) is not unlimited since not "every use" falls within the ambit of the section. ${ }^{24}$ It emphasised that section 34(1)(a) prohibits only use that affects or is likely to affect a trade mark's function as a badge of origin and does not proscribe any other use. ${ }^{25}$

So far so good: the restrictive reading of section 34(1)(a) adopted by the court must be favoured as it steers clear of proscribing innocuous use of trade marks. As the court rightly observed, "the protection of trade marks under the Act is not designed to silence commercial speech."26 This accommodative approach was underscored in Commercial Autoglass (Pty) Ltd v Bayerische Motoren Werke AktienGesellschaft, where the SCA stated that section $34(1)(a)$ proscribes only "commercial speech" that is misleading, and that use that is not misleading is protected by both trade

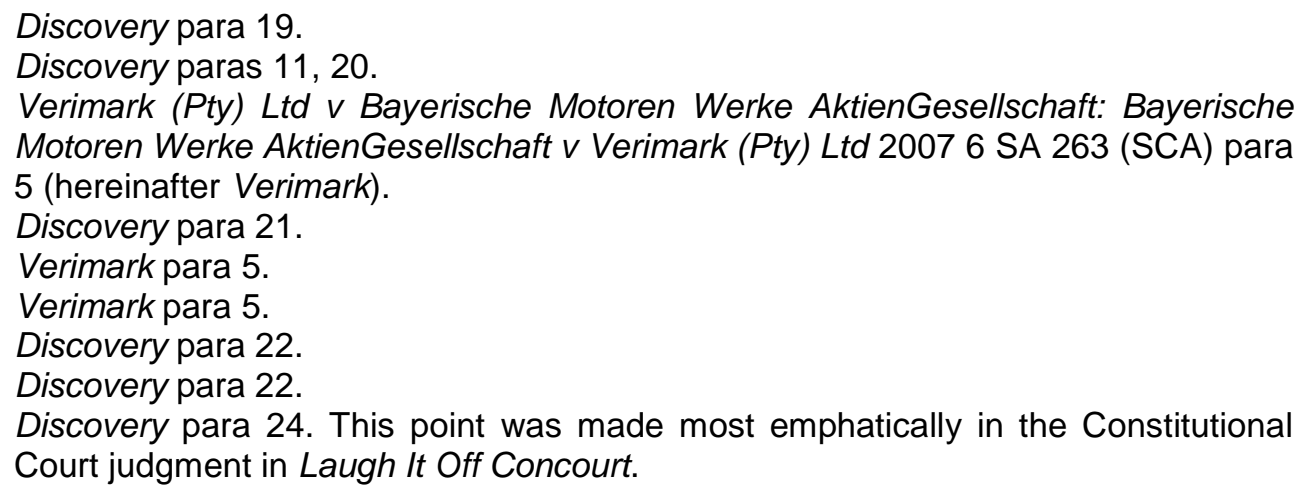


mark and constitutional principles. ${ }^{27}$ Guided by the principles enunciated by the SCA, the court framed the question for determination as to whether the unauthorised use of the trade marks

\begin{abstract}
falsely [identifies] the provenance or origin of the third party's goods or services with [those] of the trade mark proprietor, [...] [thereby] misappropriating the proprietor's badge of origin ascribed to the proprietor's own goods or services [...] through the impression created by its use of the trade mark. ${ }^{28}$
\end{abstract}

In our view there can be no quarrel with the court's formulation of the question for determination as it appropriately locates the mischief that lies in unauthorised use of a trade mark under section 34(1)(a). The primary target of section 34(1)(a) is misleading use. If the public would

perceive the [unauthorised] use of the trade mark as performing the function of a 'source identifier' for the third party's goods or services ${ }^{29}$

such use would be prohibited by section 34(1)(a). The targeted use was absent in the Discovery case. The use of the "VITALITY" trade mark by Liberty could not mislead a customer into believing that Liberty was claiming provenance in the Vitality programme or misappropriating Discovery's badge of origin in that programme. ${ }^{30}$ As the court found, an existing customer would know the origin of the Vitality programme and the possibility of customers being misled was attenuated by the fact that the quotation document and attachment were not advertised to the general public. ${ }^{31}$ The applicants did not argue that the brokers who handled the documents would be misled. ${ }^{32}$ Similar considerations applied in respect of the instruction document, as the hyperlink on the document clearly indicated the origin of the referenced Wellness programmes. ${ }^{33}$ The argument that Vitality members could be misled into believing that there is some business association between Liberty and Discovery Vitality availed no assistance to the applicants. ${ }^{34}$ The conclusion that Liberty's use of the "VITALITY" and "DISCOVERY" trade marks did not infringe section 34(1)(a) is therefore

Discovery para 24, referring to Commercial Autoglass (Pty) Ltd $v$ Bayerische Motoren Werke AktienGesellschaft 20076 SA 637 (SCA) para 8 (hereinafter Commercial Autoglass). The SCA quoted with approval the US case of Prestonettes Inc $v$ Coty 1924263 US 359 368, where it was stated that when a trade mark is used in a way that does not deceive the public, we see no sanctity in the word as to prevent its being used to tell the truth.

28 Discovery para 25.

29 Discovery para 25.

$30 \quad$ Discovery para 30.

31 Discovery paras 30, 31.

$32 \quad$ Discovery para 32.

33 Discovery para 35.

34 Discovery paras 38-39. 
justifiable as no reasonable customer could be misled by such use. ${ }^{35}$ The court considered this conclusion to balance the rights of Discovery as a proprietor and Liberty as a competitor and the public who should be able to exercise unhindered its right to free choice among competitors in the relevant market. ${ }^{36}$

The applicants' argument under section 34(1)(c) was that Liberty took unfair advantage of the "DISCOVERY" and "VITALITY" trade marks by linking them to the sale of its insurance products. ${ }^{37}$ The court proceeded on the basis that both trade marks are well-known in the Republic. The question was whether Liberty's unauthorised use took unfair advantage of the reputation of the trade marks or was detrimental to their distinctive character or repute..$^{38}$ The section 34(1)(c) argument was rejected by the court on the basis that the applicants had failed to provide evidence of actual harm or detriment to their trade marks. ${ }^{39}$ The court stressed that section 34(1)(c) does not frown upon the accrual of an advantage through the use of another's trade mark; the applicants, however, failed to surmount the "unfairness" hurdle regarding Liberty's unauthorised use of the trade marks. ${ }^{40}$ The court noted that Discovery Life and Liberty were competitors and that competition benefits consumers, cautioning against invoking section $34(1)$ (c) to stifle lawful competition. ${ }^{41}$ The court also upheld the defence raised by Liberty under section 34(2)(b). ${ }^{42}$ Accordingly, the court rejected the applicants' claims of trade mark infringement.

\subsection{The methodological flaws in the court's interpretation of sections 34(1)(a) and 34(1)(c)}

The approach adopted by the court in the Discovery case is not unprecedented as the court drew generously from the jurisprudence of the SCA. At first glance, the court's interpretation of both sections 34(1)(a) and 34(1)(c) appears unassailable. However, upon closer inspection, one discovers a methodological flaw in the court's approach with potentially debilitating effects on other protectable interests. Critically, the court ignored potential countervailing and complementary constitutional interests when

\footnotetext{
35 Discovery paras 39-40.

$36 \quad$ Discovery para 40.

$37 \quad$ Discovery para 48.

38 Discovery paras 43-44.

39 Discovery para 48. This would appear to be in line with the Constitutional Court's rejection in Laugh It Off Concourt of the SCA's acceptance of potential harm as the requisite standard for the proprietor of the trademark to prove.

$40 \quad$ Discovery paras 53-54.

$41 \quad$ Discovery para 50.

$42 \quad$ Discovery paras 58-59.
} 
determining whether there was infringement of the trade mark rights under the two sections. Overlooking these constitutional considerations resulted in the court's discarding their normative framework and considering the "matter strictly within the confines of trade mark infringement." ${ }^{43}$ Consequently, the court inherited the flawed approach adopted by the SCA in Laugh It Off Promotions CC v South African Breweries International and overturned by the Constitutional Court on appeal in Laugh It Off Concourt. ${ }^{44}$

There can be no doubt that the restriction of trade mark infringement in terms of section 34(1)(a) to "trade mark use" by the SCA is desirable as it accommodates other uses that do not threaten the interests protected by the section. We therefore do not understand the accommodative approach drawn from the jurisprudence of the SCA to be limited to trade mark use that constitutes commercial speech. In our view the restrictive approach spares uses which would have been proscribed by a literal reading of the section, regardless of whether such uses have any connection to trade. ${ }^{45}$ Attractive as it may seem, the accommodative approach does not, however, live up to the progressive transformative agenda that it appears to proffer as it simply delineates the reach of the rights conferred by section 34(1)(a) without telling us what lies on the other side of the boundary. In determining whether the allegedly infringing conduct constitutes "trade mark use", the court did not interrogate the nature of the conduct with a view to ascertaining if it constitutes protectable rights or interests. It simply determined the effect of Liberty's use on the trade mark rights (i.e. whether the conduct in question causes harm) without considering whether the use was protectable under the Constitution, in which event the first question becomes incidental. The elected interpretive path pits all alleged infringing use against the property rights conferred on the proprietor of the trade mark and can easily result in other protectable uses such as parody and commercial speech being overlooked. By analysing the conduct as a possible infringement as opposed to a potentially protected use, this statutorily-aligned demarcation of conduct resolutely favours trade mark norms by constructing the legal paradigm in which the dispute arises around trade mark rules, values and principles. ${ }^{46}$ This prevents meaningful attention from being bestowed on the

\footnotetext{
$43 \quad$ Illsley 2006 SAJHR 123.

$44 \quad$ Laugh It Off Promotions CC v South African Breweries International 20044 All SA 151 (SCA) (hereinafter Laugh It Off SCA).

45 A literal reading of the section was adopted in Abbott Laboratories v UAP Crop Care (Pty) Ltd 1999 3 SA 624 (CPD) 632 A-C and Abdulhay M Mayet Group (Pty) Ltd v Renasa Insurance Co Ltd 19994 SA 1039 (TPD) 1046 A-B.

46 A comparable analogy is found in the context of copyright law, where exceptions are not typically recognised as enforceable user rights, merely offering an exculpatory mechanism rather than being able to found a cause of action.
} 
normatively sovereign assertion of constitutionally protected conduct as per the mandate flowing from Laugh It Off Concourt. The statutory point of departure precluded the court from considering the effect of the trade marks on Liberty's right of use, and therefore fails to uphold the Constitution as the supreme legal source.

The Court in Laugh It Off Concourt ${ }^{47}$ warns against the error in placing the analysis of the infringement in private law before that of the applicable constitutional provisions, as was done in the two judgments leading up to its final successful appeal. Adjudicators should rather first construe the constitutional normative environment in which statutory interpretation is to take place, including, of course, any provisions which are relied on directly or indirectly, but also the broader transformative context of the constitutional project and its systemic objectives and aspirations. Once this interpretive context has been set, the statutory provisions can be construed in this normative environment as per the first principle of subsidiarity. By first assessing the constitutional protections afforded to the expressive conduct, the statutory concept of fairness is informed by constitutional norms. The approach enunciated in Laugh It Off Concourt suffuses statutory interpretation with constitutional norms as required by section 39(2) of the Constitution and it does so without offending the principles of subsidiarity. This transformation-oriented methodology is clearly preferable to operating as if the Constitution meekly acquiesces to whatever content the doctrine has assumed in the private law field so long as it is not in blatant conflict with a constitutional provision. This applies equally to common law norms manifest in normative legal constructs like wrongfulness in the realm of unlawful competition, discussed below.

The methodological approach in Laugh It Off Concourt pays homage to the supremacy of the Constitution, its normative values and the transformative purpose of section 39(2), which requires courts to promote "the spirit, purport and objects of the Bill of Rights" when interpreting any legislation. ${ }^{48}$ When interpreting rights conferred by legislation such as trade mark rights, courts must do so in a manner that is "consistent with" the Bill of Rights ${ }^{49}$ and

must promote the values that underlie an open and democratic society based on human dignity, equality and freedom. ${ }^{50}$

\footnotetext{
$47 \quad$ Laugh It Off Concourt para 43.

48 Section 39(2) of the Constitution of the Republic of South Africa, 1996 (hereinafter the Constitution).

49 Section 39(3) of the Constitution.

50 Section 39(1)(a) of the Constitution. Emphasis added.
} 
This is especially important in cases of pre-constitutional legislation, as these instruments cannot be presumed to have constitutional values and objectives at heart, and new renderings of old doctrines may be necessary.

The constitutional imperative created by these provisions requires that intellectual property rights be granted and exercised in a manner that is - at a minimum - consistent with the rights in the Bill of Rights. The consistency cannot be ascertained without first determining the nature of the implicated rights in the Bill of Rights. Where legislation creating intellectual property rights limits any right in the Bill of Rights, it must do so in a manner that is sanctioned by the limitation clause. ${ }^{51}$ Thus, when resolving the conflict between the rights conferred by legislation and the rights in the Bill of Rights, a court must take into account the factors enumerated in the limitation clause as mirrored in the legislation concerned. ${ }^{52}$ However, these factors comprised by the statutory provisions - cannot be investigated without knowing the ambit of the right that is subject to limitation, which logically requires that the right itself be construed before the statutory limitation to the right is contemplated. ${ }^{53}$ In this way the normative framework created by these constitutional provisions asserts itself whenever resolving conflicts between constitutional rights and rights conferred by legislation.

The court in Discovery did not interrogate the protectable nature of Liberty's use. It simply concluded that the use was not infringing Discovery's trade mark rights without first determining whether such use enjoys any form of legal protection. ${ }^{54}$ The approach seems innocuous but may result in "some expressive conduct of at least equal cogency and worth in our broader society" being sidelined without recognition. ${ }^{55}$ The court began the enquiry at the tail-end by considering whether Liberty's use impinged on Discovery's trade mark rights. On this approach, one ends up only assessing the effect

51 Section 36(1) of the Constitution.

52 The factors adumbrated in s 36(1) of the Constitution are: the nature of the right; the importance of the purpose of the limitation; the nature and extent of the limitation; the relation between the limitation and its purpose; and less restrictive means to achieve the purpose.

$53 \quad$ In Midi Television (Pty) Ltd v Director of Public Prosecutions (Western Cape) 2007 3 All SA 318 (SCA) paras 9 and 11, it was stated that reconciling expressive conduct with other rights requires a court to consider the extent to which each right intrudes into the space of another. Such an analysis is impossible to embark on when the ambit of a competing right has not been delineated.

54 See in this regard the judgment of Sachs $\mathrm{J}$ in Laugh It Off Concourt para 75, where he states: "The issue before us, however, is not whether it rubs us up the wrong way or whether Laugh It Off's provocations were brave or foolhardy, funny or silly. The question we have to consider is whether they were legally and constitutionally permissible." Emphasis added. 
of the alleged infringing use on trade mark rights, which is, according to the ratio decidendi in Laugh It Off Concourt, immaterial to whether the use is legally protected, but invariably ends up constructing the metrics of fairness against which the use is measured. The approach departs on the premise that the alleged use enjoys no legal or constitutional protection because that is what the statutory regime subtly imbibes into the reasoning of the adjudicator. Instead, the court should have first determined whether the use was protected as opposed to automatically deeming it a potential limitation of Discovery's trade mark rights.

The constitutional methodology in Laugh It Off Concourt shows that the twostep approach to section 16 involves first the interpretation of the provision, ascertaining whether the conduct in question falls to be protected and to what extent. The limitation analysis follows this assessment, where it is determined whether the (statutory, in this case) limitation of the right is justifiable. Accordingly, on the second step of the analysis, it should be determined whether the finding of infringement that would result from the successful reliance on section 34(1)(a) or 34(1)(c) would unjustifiably limit the speech of the respondent. This analysis is entirely separate from whether infringement has occurred, which can take place only once it has been established that the respondent's speech would not be unjustifiably limited by such a finding.

The typifying iterations of speech in subsection (1) are indicative of the importance of the types of conduct to the constitutional project. Accordingly, the type of speech involved may be so important as to all but resolve the matter: it is cloaked in an armour of constitutional protection that no trade mark infringement claim could hope to penetrate ${ }^{56}$ Alternatively, even if the speech is not listed as one of the forms identified in section 16(1)(a)-(d), it can still come in for protection if it is not disqualified by the exclusions clause in section 16(2). In other words, all speech that is not prohibited by the exclusions clause qualifies to be protected in principle, though under the limitation test the relative (un)importance of the protection may unravel the apparent protection garnered under the first step. ${ }^{57}$ False speech, for example, would qualify for protection but, if the allegation is that the speech is false, whether academic or press speech, then the limitation analysis should conclude that the relevant analysis of the infringement of rights under the body of private law governing the conduct (for example, defamation or

56 This is the finding of the Constitutional Court in Laugh It Off Concourt.

57 Islamic Unity Convention v Independent Broadcasting Authority 20024 SA 294 (CC) paras 31-33; De Reuck v Director of Public Prosecutions (Witwatersrand Local Division) 20041 SA 406 (CC) para 47. 
trademark infringement) adequately reflects the constitutional interest in its structure and approach, whether in proving the requirement of truthfulness or establishing the standard of unfairness, or protections of media freedom in the form of delictual exceptions. The amount of protection it receives in private law should approximate the importance of the speech to the constitutional project, both generally and contextually. Equally, the constitutional gravity of the competing interest must be accounted for.

Determining the nature of expressive conduct (non-trade mark commercial use in this case) is therefore essential for locating the expression in the appropriate constitutional context and ascertaining the level of protection that the expression enjoys in the constitutional value system. In Discovery the court could have recognised Liberty's use as a form of commercial speech in line with the SCA cases it relied on. ${ }^{58}$ The court could also have regarded the case as involving the rights of consumers to receive and impart information within the remit of section 16(1)(b) of the Constitution. This would have allowed the court to plot the use (expression) on the constitutional landscape and properly gauge the weight that our democratic society attaches to it. ${ }^{59} \mathrm{~A}$ court confronted with expressive conduct, whether or not the expression is commercial, must engage in a searching analysis to consider whether such conduct is protected and if so, to what extent. ${ }^{60}$

Once the conduct covered by the asserted constitutional right has been plotted on the constitutional landscape, the judicial inquiry can proceed to

58 One would have thought that in para 24 of the judgment the court was going to expressly recognise Liberty's use as a form of commercial speech. In British American Tobacco South Africa (Pty) Ltd v Minister of Health 20123 All SA 593 (SCA) paras 9 and 25; City of Cape Town v Ad Outpost (Pty) Ltd 20002 SA 733 (C) 749D-E; North Central Local Council and South Central Local Council v Roundabout Outdoor (Pty) Ltd 20022 SA 625 (D) 633D-E, the courts held that s 16(1) of the Constitution protects commercial speech. Commenting on the ambit of $s$ 16(1), Nel points out that the section is "wide enough to cover about any form of expression" (Nel 2004 CILSA 65). Similarly, Mills holds the view that "commercial speech and advertising in particular also fall within the ambit of speech which receives constitutional protection" (Mills 2014 PELJ 270).

59 The need to first locate any form of expression within s 16(2) of the Constitution guards against the "tendency to conclude uncritically" that certain forms of expression (which may be conveniently lumped as non-trade mark use in this case) deserve less constitutional protection than well-known forms of expressions such as "political or artistic speech" (City of Cape Town v Ad Outpost (Pty) Ltd 20002 SA 733 (C) 749D-E).

60 In S v Mamabolo 20013 SA 409 (CC) para 37 the Constitutional Court counselled that courts must "be particularly astute to outlaw any form of thought control, however respectably dressed." In the context of commercial speech, the determination must also occur against the backdrop of s 8(4) of the Constitution, which provides that a juristic person is entitled to the rights in the Bill of Rights to the extent required by the nature of the rights and the nature of that juristic person. 
the statutory infringement analysis. The proper identification of countervailing interests when interpreting sections $34(1)(a)$ and $34(1)(c)$ is crucial as it guides the court towards the applicable framework and allows it to attach due weight to the identified interests and balance them appropriately. However, plotting a protectable interest on the appropriate constitutional landscape is not enough as a court must also attach the appropriate weight to the identified interest. In South African Broadcasting Corporation Ltd $v$ Downer the SCA properly located the implicated rights on the applicable constitutional landscape but failed to attach due weight to them in the limitation analysis. ${ }^{61}$ The methodological flaw in the SCA's approach in that decision was that although it identified freedom of expression as a competing right, it attached negligible weight to the right and presumptively privileged the opposing right without mentioning why. ${ }^{62}$ The court assessed the impact of freedom of expression on the right to a fair trial but failed to assess the impact of the latter on freedom of expression as a protectable right, thereby failing to strike any compromising balance between the respective rights. ${ }^{63}$ The approach was criticised by Moseneke DCJ and Mokgoro $\mathrm{J}$ in their respective dissenting judgments on appeal to the Constitutional Court. ${ }^{64}$ Moseneke DCJ found that the approach "privileges the right to a fair trial over the right to freedom of expression" and "implies an inappropriate and unwarranted hierarchy of rights." 65 He posited that reconciling competing rights requires courts to "embark upon a

61 South African Broadcasting Corporation Ltd v Downer 20071 All SA 384 (SCA) paras 14 and 20 . The court was required to resolve the conflict between the rights to access to court and fair trial on the one hand and the right to freedom of expression on the other, which are protected in ss 16, 34 and 35(3) of the Constitution, respectively. In reconciling the rights, the court formulated the question as whether the applicant's right to freedom of expression "should prevail at the expense of the respondents' competing constitutional rights." The court found that the right to fair trial could not "give way in this clash of rights" and that freedom of expression "should not be allowed unless the court is satisfied that justice will not be inhibited rather than to adopt the converse test."

62 The issue of attaching due weight to an identified protectable right is also clear from Independent Outdoor Media v City of Cape Town 20132 All SA 679 (SCA) para 25, where Leach JA simply stated: "I have not lost sight of the fact that commercial speech is worthy of protection." Although the statement was said in relation to the impact of an impugned Bylaw, it is nonetheless indicative of the light weight attached to the right that was so easily dismissed when analysing the impact of the Bylaw on the right.

63 Danay and Foster 2006 SAJHR 582 criticise the SCA's approach as creating "a rebuttable presumption favouring fair trial rights over free press rights."

64 South African Broadcasting Corporation Ltd $v$ National Director of Public Prosecutions 20071 SA 523 (CC) (hereinafter SABC v NDPP).

65 $S A B C \vee N D P P$ para 103. 
nuanced analysis" as opposed to "simply opting" for one right to prevail over another. ${ }^{66}$ Mokgoro $\mathrm{J}$ similarly pointed out that

a court must balance the conflicting rights proportionally. Our Constitution does not envisage a hierarchy of rights where courts simply prefer one right over the other. ${ }^{67}$

She also emphasised the need to formally "acknowledge" the applicant's right to freedom of expression in balancing competing rights. ${ }^{68}$ In Discovery the court failed in both legs of the enquiry. Firstly, it failed to consider Liberty's use as a protectable interest. Secondly, it attached negligible weight to Liberty's use as it did not consider the adverse impact of proscribing it. The court fell into the trap of presumptively privileging trade mark rights over potentially protectable use by considering such use as an exception to the infringement of trade mark rights or as non-offending conduct. 69

A similarly flawed approach was adopted by the SCA in Laugh It Off SCA. ${ }^{70}$ The court anteriorly determined whether the applicant's conduct infringed section 34(1)(c) and considered whether the infringement was excused by freedom of expression only secondarily. ${ }^{71}$ The approach was unanimously rejected by the Constitutional Court on appeal. ${ }^{72}$ The Constitutional Court reasoned that a finding of infringement hinged on "whether the offending expression is protected under section 16(1) of the Constitution or not." ${ }^{73}$ If protected, "what is unfair or detrimental, or not" under section 34(1)(c) must "be mediated against the competing claim for free expression."74 The Constitutional Court reasoned that the SCA's flawed approach "prevents an understanding of the internal requirements of the section through the lens of the Constitution. ${ }^{75}$ The approach clearly privileges trade mark rights as it considers only the effect of the expressive conduct on the well-known trade mark and allows this outcome to determine the constitutional protectability of the speech. The SCA was precluded from considering the impact of the trade mark on the expressive conduct by its failure to

$66 \quad S A B C \vee N D P P$ para 102.

$67 \quad S A B C \vee N D P P$ para 125.

$68 \quad S A B C \vee N D P P$ para 123.

69 The approach which privileges trade mark rights over protected expressive conduct was rejected by the Constitutional Court in Laugh It Off Concourt para 44. The court stated that a court reconciling these competing interests must "balance out the interests of the owner of the marks against the claim of free expression."

Laugh It Off SCA.

Laugh It Off SCA paras 23 and 28.

Laugh It Off Concourt para 43.

Laugh It Off Concourt para 44.

Laugh It Off Concourt para 44.

Laugh It Off Concourt para 44. 
determine whether the conduct was protected. In Discovery the court committed a similar methodological error.

The fundamental difference between the SCA's approach and that of the Constitutional Court in Laugh It Off Concourt is that the former characterised the purpose of the applicant's conduct as a "factor" potentially justifying an infringement of section $34(1)(c)$ while the latter characterised it as a protected competing right. ${ }^{76}$ In Discovery the court also erred when interpreting section 34(1)(a), as it merely characterised Liberty's use as nontrade mark use. Similarly, when determining whether there was infringement of section 34(1)(c), it simply enquired "whether Liberty's use of the marks will take unfair advantage of, or will be detrimental to, the distinctive character or repute associated with the marks."77 Again, this approach began at the tail-end of the enquiry and consequently missed the point that the Constitutional Court was at pains to emphasise in Laugh It Off Concourt. It haphazardly considered the impact of Liberty's use on the applicants' trade mark rights in terms of section $34(1)$ (c). No attempt was made to establish the protectable nature of the use, which would have precluded the possibility of the use constituting trade mark infringement, thereby rendering the statutory analyses redundant. Ironically, in Discovery the court referred to the Constitutional Court's caveat in Laugh It Off Concourt that courts

\begin{abstract}
must be astute not to convert the anti-dilution safeguard of renowned trade marks usually controlled by powerful financial interests into a monopoly adverse to other claims of expressive conduct. ${ }^{78}$
\end{abstract}

The court righty acknowledged that

section 34(1)(c) should not be used in such a way that it prevents a proper balance between the competing interests involved. ${ }^{79}$

Regrettably, the court failed to identify Liberty's competing interests and locate them on the applicable framework.

Our view is that the lack of assiduity to legally protectable competing interests involved in trade mark infringement cases logically affects the balancing process, as that process cannot occur without first identifying implicated competing interests and locating them in the applicable legal

76 Compare paras 28 and 37 of Laugh It Off SCA and paras 43-44 of Laugh It Off Concourt.

77 Discovery para 44.

78 Discovery para 51 quoting from para 48 of Laugh It Off Concourt. Admittedly, the Discovery court's decision does manage to arrive at an outcome that does not bestow any additional monopoly on the trade mark proprietor, but entirely neglects the deeper significance of the methodological reordering.

79 Discovery para 51. 
framework. ${ }^{80}$ In Discovery the court rushed to consider the impact of Liberty's "use" on the applicants' trade mark rights, and its failure to properly characterise Liberty's "use" as a protectable right resulted in the relegation of such "use" to a legally unidentifiable use which threatens the applicants' trade mark rights. The use was analysed as a potential limitation to the applicants' trade mark rights as opposed to conduct protected by constitutional edict. This resulted in a one-sided analysis which privileged trade mark rights. The approach is inconsistent with section 39(3) of the Constitution and the approach adopted by the majority of the Constitutional Court in Laugh It Off Concourt. This approach, which takes its cue from previous decisions of the SCA,${ }^{81}$ is undesirable as it is not anchored in the constitutional normative framework and allows a court to have a "free-hand" when resolving disputes involving trade mark law. The approach also allows a court to lump all use together under either "trade mark use" or "non-trade mark use" without considering their protectable nature, which may result in some protected uses being sidelined in the process. ${ }^{82}$ The court in Discovery may perhaps be forgiven because, unlike in Laugh It Off, Liberty did not argue that its use constituted protected expressive conduct. However, the court ought to have been alive to such considerations in line with the injunction imposed by section 39(2) of the Constitution.

Because the court failed to unpack the section 16 right as applicable in the situation, it also did not reveal that the right extends to those receiving information as well as those imparting it (section 16(1)(b)), thereby implicating the rights of consumers in this matter. ${ }^{83}$ The information itself was not proprietary and consumers were found to have the strongest right

80 It is not possible to identify the applicable normative baseline without first identifying the applicable right. In Giddey v JC Barnard 20075 SA 525 (CC) para 15 O'Regan $\mathrm{J}$ first identified the right to access to courts and then found its "normative base in the rule of law".

81 The Discovery court referred to the SCA decision in Commercial Autoglass para 8. In this case the SCA again made constitutional law subject to the operation of trade mark principles, pretending that the two cover exactly the same notional area by stating that: "Trade mark use that is not misleading (in the sense of suggesting provenance by the trade mark owner) is protected, not only constitutionally but in terms of ordinary trade mark principles." This is the first and last time the Constitution is mentioned in the decision (both other references being necessitated by rehearsing the appellant's argument). The court summarily dismisses the possibility that the Constitution says anything different from what the Trade Marks Act says, without even considering the provision relied on, much less giving it the necessary construction or interpretation, simply deciding that it says exactly what the "ordinary trade mark principles" proclaim.

Du Bois 2012 SA Merc LJ 177. The author points out that intellectual property rights may be limited by some protectable interests like freedom of expression. unlawful competition: Discovery paras 88-89. 
to the use and dissemination of that information. In our view, the Vitality members' rights to receive and impart their personal information under section 16(1)(b) of the Constitution were implicated and should have featured clearly in the court's analysis instead of being lumped together with Liberty's use as non-infringing use.

\subsection{The court's approach to the claim of unlawful competition}

The court's treatment of the claim of unlawful competition centred on the delictual element of wrongfulness. The court's approach to the unlawful competition claim is essentially no different from that of trade mark infringement as it subverted certain competing interests when assessing the element of wrongfulness. This interpretation of the element of wrongfulness is scanty and somewhat detached from the facts of the case. The mainstay of the applicants' unlawful competition claim was that Liberty "misappropriated" their "performance" by using their customers' Vitality status to calculate its Wellness Score and by "indirectly appropriating the underlying Vitality programme and business system." ${ }^{84}$ The court's point of departure was that the alleged appropriation of a rival's goodwill or performance is not one of the "recognised illegalities" against which unlawful competition has traditionally provided protection. ${ }^{85}$ This does not mean, however, that the conduct cannot be brought under the awning of delictual liability: "[t]he real question is whether the conduct complained of, however it is labelled, is wrongful." 86

The court modelled its approach on the Constitutional Court's decision in Phumelela, ${ }^{87}$ where the element of wrongfulness in the Aquilian action hinged on the constitutional values that comprise contemporary boni mores. ${ }^{88}$ This determination was undertaken by weighing relevant factors against one another, informed by the ostensibly competing rights to property and freedom of trade in sections 25 and 22 of the Constitution respectively. ${ }^{89}$ As such, the unlawful competition claim rested on a weighing up of the right to freedom of trade in section 22 against the company's goodwill, treated as a property interest in terms of the property clause, under the conceptual cover of wrongfulness.

Section 22 of the Constitution states:

\footnotetext{
84 Discovery para 66. This is what the applicants referred to as the back-office.

85 Discovery para 67.

$86 \quad$ Discovery para 67.

87 Phumelela.

88 Discovery paras 62-63.

$89 \quad$ Discovery para 64.
} 
Every citizen has the right to choose their trade, occupation or profession freely [but the] practice of a trade, occupation or profession may be regulated by law.

This provision must find both vertical and horizontal operation for it to secure its object. Section 22 grants a vertical right in the traditional liberal sense, i.e. one that entrenches individual liberty against state incursion. ${ }^{90}$ This iteration of the value of personal liberty (which is extended to juristic persons where applicable) guarantees that constitutional standards of justification pertain to any regulation of such freedom in an individual's choice and practice of a profession. Further, while the practice of one's trade may be regulated by the state, a similar power should not be lightly extended to the private sector, and this right can also be asserted in horizontal disputes. ${ }^{91}$ Indeed, section 22 of the Constitution prevents private parties from exercising legal or economic power to impede other private parties from freely partaking in the regulated market economy when such restraint is contrary to public policy. ${ }^{92}$ Contractual provisions between private parties are always subject to constitutional validation, ${ }^{93}$ showing that the value of liberty applies against private power as well as public.

As mentioned above, the delict of unlawful competition is contingent on a finding of wrongfulness, ${ }^{94}$ which element is established by weighing up relevant factors to determine whether the conduct complained of conflicts with the public boni mores. This is the port of entry for all normative

90 For an exposition of the scope of $\mathrm{s} 22$ of the Constitution, see Affordable Medicines Trust $v$ Minister of Health 20063 SA 247 (CC) paras 58-66.

91 The application of the right is extended by s 8(2) of the Constitution, which states: "A provision of the Bill of Rights binds a natural or a juristic person if, and to the extent that, it is applicable, taking into account the nature of the right and the nature of any duty imposed by the right." This was recognised by the court in Discovery para 87 , on the basis that monopoly powers are detrimental to public welfare, crediting this insight to the Laugh It Off Concourt bench.

Courts have recognised that public boni mores play a role in restraint of trade cases: Motherland Design Agency (Pty) Ltd v Whitefernfranc (Pty) Ltd 2020 ZALCJHB 145 (31 August 2020) para 59, quoting Strike Productions (Pty) Ltd $v$ Bon View Trading 131 (Pty) Ltd 2011 ZAGPJHC 1 (20 January 2011) paras 26-30, 54 (and the authorities quoted there) and Reddy $v$ Siemens Telecommunications (Pty) Ltd 2007 2 SA 486 (SCA) paras 10-16, 20-21 (hereinafter Reddy). The onus to show that a restraint of trade clause is unreasonable and contrary to public policy was first introduced into South African law in Magna Alloys \& Research (SA) (Pty) Ltd v Ellis 19844 SA 874 (A), where the court reversed the English law approach that had been followed up to that point of requiring the party relying on the agreement to show that it is reasonable and valid: see Reddy para 10. The restraint of trade analogy in the context of competition law was similarly employed by the Constitutional Court in Masstores (Pty) Limited v Pick $n$ Pay Retailers (Pty) Limited 20171 SA 613 (CC) para 35 (hereinafter Masstores). See further Currie and De Waal Bill of Rights Handbook 469-471 and the cases discussed there. Neethling Unlawful Competition 79. 
considerations that are drawn from the industry in which the parties compete, the considerations that have been embedded in the law of unlawful competition through case law and, importantly, the rights and principles found in the Constitution. This analysis revealed to the court the clear conclusion that the conduct was not wrongful, making the remaining elements of the delict irrelevant and allowing the court to decline the invitation to develop the common law to recognise this new application of delictual principles.

Ultimately, the unlawful competition claim was correctly rejected by the court on the simple basis that the parties were not direct competitors, and equally that the corporate entity that was in direct competition with the respondent had no proprietary claim over the information used. The court ended up not having to develop the common law to adequately capture the import of the constitutional interests in play, and merely applied the factors that are employed to determine wrongfulness to the facts at hand, finding that the element of wrongfulness - as an incarnation of the boni mores of the constitutional society - was absent. Accordingly, the unlawful competition claim was rejected along with the two claims of trade mark infringement. The application was dismissed with costs.

\title{
2.5 The methodological vagueness of the court's approach to unlawful competition
}

\begin{abstract}
What is clear is that the High Courts and the Supreme Court of Appeal should at all times view the interpretation of legislation as well as the development of the common law and customary law in light of the spirit, purport and objects of the Bill of Rights. It is accordingly necessary that the provisions of section 39(2) should always be borne in mind by these courts. This is particularly so when the court is engaged with applying an open textured normative rule, such as wrongfulness or fairness, to a set of facts. ${ }^{95}$
\end{abstract}

The Laugh It Off Concourt and Phumelela decisions explicitly invoke section 39(2) of the Constitution as the textual basis for their judicial treatment of the respective disputes, although the former was concerned with statutory interpretation and the latter with common law application and development. The Laugh It Off Concourt judgment found that there was no conflict upon a proper interpretation of the apparently conflicting sources of law, placed in their appropriate methodological position, while the latter decision held that the common law property right to goodwill, upon proper construction, does not conflict with freedom of trade. Against this background, it seems 
clear that when courts encounter this type of case they should follow the section 39(2) directive "at all times",

particularly so when the court is engaged with applying an open textured rule, such as wrongfulness or fairness, to a set of facts. ${ }^{96}$

In accordance with section 39(2), courts cannot merely weigh whichever constitutional rights have been argued and then consider themselves constitutionally virile. Instead, the dispute should be explicitly situated in the broader normative context that the Bill of Rights poses. Such analysis requires the interests to be viewed in the appropriate political and historical context, including the transformative vision of the constitutional document and project, before construing the rights in dispute. ${ }^{97}$ In developing the common law of unlawful competition, the approach would also entail embracing new interests that may be worthy of veneration in our constitutional project. The case of Phumelela is indeed

authority for the proposition that the boni mores or reasonableness criterion must be used to establish wrongfulness in cases not covered by existing precedent. ${ }^{98}$

The Discovery case presented an opportunity to "refine" the application of the test for wrongfulness in the law of delict - one that "questions the reasonableness of imposing liability" in the context of competition law. ${ }^{99}$ Much like in restraint of trade cases, such an approach would question the reasonableness of limiting the implicated rights of both Liberty and the Vitality members to protect the applicants' proclaimed rights. ${ }^{100}$

The rivalling constitutional interests that the Constitutional Court had to weigh when determining the limits of lawful competition in Phumelela were principally the right to property and freedom of trade. ${ }^{101}$ These are, however, not the only constitutional interests that a court is required to weigh when applying the boni mores criterion. ${ }^{102}$ It is in recognising this that the Constitutional Court in Phumelela pointed out that determining the limits of

\footnotetext{
$96 \quad$ Phumelela para 26.

97 Hyundai para 21.

$98 \quad$ Masstores para 48

$99 \quad$ Masstores para 48; Loureiro v Mvula Quality Protection (Pty) Ltd 20143 SA 394 (CC) para 53; Country Cloud Trading CC v MEC, Department of Infrastructure Development, Gauteng 20151 SA 1 (CC) para 26.

100 Neethling 2008 SA Merc LJ 415-416; CTP Ltd v Argus Holdings Ltd 19954 SA 774 (A) 784 .

$101 \quad$ Phumelela para 33.

102 The court focussed on the right to property and the right to freedom of trade because they were implicated in that case but noted that the Bill of Rights "also promotes and protects other freedoms." The court therefore did not close up the list of rights or interests that a court may be required to weigh in a particular case.
} 
lawful competition takes account of "many factors" and "necessitates a process of weighing up interests that may in the circumstances be in conflict."103 The applicability of other interests (apart from those of the litigants) is determined in terms of the facts of a particular case and such interests cannot simply be subsumed under the rivalling interests of the litigants or treated as ragbags that augment a court's finding in favour of a particular interest asserted by a litigant. ${ }^{104}$ The prevailing boni mores may indeed dictate that a court weighs up other interests or constitutional rights apart from those of the litigating parties when determining wrongfulness. ${ }^{105}$ In modelling its approach on Phumelela, the court in Discovery essentially limited its analysis to the two rights that were implicated in Phumelela when examining the boni mores criterion, notwithstanding its statement that "the weighing-up exercise is not limited only to the interests of the disputing parties." 106 The court failed to apply the principles enunciated in Phumelela beyond the strictures of precedent as dictated by the factual matrix of the Discovery case.

In Discovery, there is no indication that the court recognised that interpretation (as an adjudicative task) takes place in a broader context than that created by the two ostensibly competing rights of property and freedom of trade, despite factors like the consumers' proprietary interests featuring in the trade mark analysis. ${ }^{107}$ Indeed, the public interest is seemingly

103 Phumelela para 32.

104 In Phumelela para 35, the Constitutional Court declined the invitation to confine the analysis of wrongfulness to the impact of $s 25$ of the Constitution when promoting the spirit, purport and objects of the Bill of Rights. In Discovery (paras 87-88) the court subsumed the Vitality Members' interests under the "public interest" factor and employed it to ensure that in "balancing the other two interests the benefit of competition in trade is not lost."

105 Decisions dealing with the reasonableness of enforcing a restraint of trade are instructive in this regard. In Reddy para 16 the court stated that "a restraint which is reasonable as between the parties may for some other reason be contrary to the public interest." In Basson v Chilwan 19933 SA 742 (A) 767 the court stated that when considering the reasonableness of a restraint a court should consider whether there is an aspect of public policy which has nothing to do with the relationship between the parties that requires that the restraint be maintained or rejected. The approach entails recognising other interests as independent and weighty factors that may sway a court to reach a certain conclusion when weighing competing interests. Discovery para 87.

The court even acknowledges this (Discovery para 87): "the weighing-up exercise is not limited only to the interests of the disputing parties". Unfortunately, the court then discarded this sentiment when it ascribed the concept as an ever-present "inherent factor in the equation", additionally explaining that "the protection of competition in matters of trade benefits the public welfare." By doing so, the court first reduced the public interest to an intrinsic component in the judicial analysis of the public boni mores, tacitly not worth its own exposition or incarnation, and followed this up by sweeping aside the entire concept by rendering it no more than an effect or result of 
captured by the reasons for protecting each respective right rather than animated with its own content, external to the bifurcated construction of relevant interests that could expand the binary, back-and-forth "weighing" of rights to include exogenous concerns and outcomes. ${ }^{108}$ This is demonstrated when the court asks:

What do the boni mores of current day South Africa suggest, having regard to the competing constitutional interests of the parties? ${ }^{109}$

Accordingly, the public interest is seen as not only centred in but exhausted by the "competing constitutional interests of the parties", being extrapolated from the individual rights asserted by the litigants and confined to this notional ambit. ${ }^{110}$ This may reveal that there is a significant public or constitutional interest in how the case is resolved that is not reflected in either right in issue, which should then be placed centrally rather than at the periphery of the dispute.

Without being too prescriptive about the appropriate constitutional markers to direct the enquiry, a variety of provisions may feature that would elevate the impact of the present dispute beyond its own remit. The privacy and attendant human dignity interests held by the public (Vitality members) cannot be reduced to a financial interest in the price charged on life insurance policies. ${ }^{111}$ Upholding the applicants' claim would have meant

the protection of the individual right. Nothing outside the confines of the ss 22 and 25 rights is ever contemplated as an instantiation of the public interest.

108 Discovery paras 87-91.

109 Discovery para 74.

110 In Discovery para 77 the court anchors this approach in the following quote from Langa CJ in Phumelela (para 36): "The Bill of Rights does not expressly promote competition principles, but the right to freedom of trade, enshrined in section 22 of the Constitution is, in my view, consistent with a competitive regime in matters of trade and the recognition of the protection of competition as being in the public welfare." Regrettably, the court arguably ignored the immediately preceding paragraph, where the relevance of the $s 22$ right is explained: "The process of weighing up must include consideration of other provisions of the Bill of Rights which might be relevant to the issue." Further, the paragraph following the one quoted by the Discovery court reads: "It is not permissible for a litigant to simply carve out those provisions that are favourable to it in the application of section 39(2). The interests of other holders of rights must also be taken into account in the balancing exercise."

111 In Discovery para 68.4, the court acknowledged that the Vitality members' status was the "members' personal information" and that they were "free to make it public". In para 88 the court observed that the members were at liberty to disclose their personal information to whosoever they preferred and to use it for "whatever lawful reason they may wish". The personal nature of the disclosed information certainly underscores the constitutional right to privacy in s 14 of the Constitution while the voluntary disclosure of the information to a recipient of choice underlines individual autonomy and therefore the right to dignity of the members as enshrined in $\mathrm{s} 10$ of the Constitution. The link between these two rights was recognised by the Constitutional Court in Khumalo v Holomisa 20025 SA 401 (CC) para 27. 
that Vitality members were precluded from using their personal information on account of the applicants' proclaimed property rights. This would have been a clear incursion into the Vitality members' right to dignity and freedom of expression, and probably the right to privacy to boot, which calls for proper balancing in the weighing-up process. ${ }^{112}$ In weighing up only Liberty's right to trade against the applicants' claimed property rights, the court inexplicably subverted the interests of the Vitality members under the competing interests of the litigants. ${ }^{113}$ The public interest in innovation (of the marketplace and the insurance industry) is also not reflected in any of the factors that are considered. The basic contours of the business paradigm are further implicated (in a prescriptive sense) by the norms that the court recognises and endorses: whether business operators are encouraged or even permitted to recognise existing offerings and incorporate these into their services to the public. ${ }^{114}$ Further, the right to freedom of expression could also inform the application of the common law, both as a right and as an incarnation of the public interest in living in a type of society where commercial and non-commercial expression is jealously guarded as a democratic ideal. ${ }^{115}$ This right as well as numerous other rights

112 The Vitality members' ability to partake in economic activities for the betterment of their social and economic lives without undue hindrance (such as concluding voluntary contracts with Liberty using their personal information) is emblematic of the doctrine of pacta sunt servanda - a component of public policy which also underscores individual autonomy and human dignity. See Barkhuizen v Napier 2007 5 SA 323 (CC) paras 15 and 30; Country Cloud Trading CC v MEC, Department of Infrastructure Development, Gauteng 20151 SA 1 (CC) para 65; and Paulsen v Slip Knot Investments 777 (Pty) Limited 20153 SA 479 (CC) paras 71-72. The other dimension of the issue for determination by the Discovery court could therefore have been whether it is reasonable to limit Vitality members' rights to contract with other service providers (Liberty) using their personal information in order to protect Discovery's claimed proprietary interests.

113 In Discovery para 78 the court analysed the boni mores criterion only in connection with Liberty's rights vis-à-vis the applicants' claimed property rights: "[l]n order to find that Liberty's conduct is wrongful, I would have to find that it is contrary to the boni mores of our society for Liberty to use publicly available information, voluntarily provided by a paid-up Vitality member who seeks insurance from Liberty, as a risk proxy and basis for calculating a Liberty customer's Wellness Score under the Wellness Bonus scheme."

114 Despite repeatedly alluding to the public's interest in a competitive market, there is no reference to the impact that this decision could have on the way in which businesses are operated - the ability to pursue a particular business model or offer a given product or service - by large and small entities alike, nor the direction and content that this decision necessarily gives to prevailing commercial norms, whichever way it is decided.

115 Discovery para 74. The court's subconscious subversion of Liberty's right to expression under Discovery's claimed proprietary interests is clear from the manner in which it couched the question for determination: "Is it wrongful for Liberty to use the non-proprietary and publicly available Vitality status of Vitality members as a risk proxy for calculating Liberty's own Wellness Score for marketing and selling its Wellness Bonus add-on to its Liberty Plan, which competes with Discovery Life's 
weighed so heavily in the trade mark infringement analysis that its sudden disappearance seems strange. Seen in this way, the dispute ultimately comes down to how much deference South African constitutional society is willing to grant the commercial preference for expansive control over anything tangentially related to one's business operations.

When it comes to unlawful competition, the only relevant public interest that the court locates is in a competitive marketplace, and this is rooted in public policy as a general, common sense consideration rather than being rooted in any constitutional necessity. Accordingly, the section 22 right is cast as the reification of the public interest in the traditional sense ${ }^{116}$ in that it secures to the public a marketplace free from arbitrary constraint. ${ }^{117}$ This treats the constitutional right as the result of sound policy instead of being a clear incarnation of and enjoying an unmediated relationship with individual liberty, or as a constituent guarantee in a larger scheme of normative rules. While the decision undoubtedly fell on the correct side of the legal question, it was perhaps a little skittish in its willingness to show its thinking or embrace wider modalities of interest.

The court was asked to follow a "group wrong" approach - it was common cause that Discovery Vitality and Liberty were not direct competitors as they offered different products in different markets, meaning that the court would have to develop the law to recognise distinct corporations as the same

policy?" To underscore the essence of Liberty's right to expression, the court could have queried the reasonableness of limiting Liberty's right of expression on the basis of using the publicly available Vitality status of Vitality members.

116 Raz Ethics in the Public Domain 37 explains the traditional use of the term "in which it refers not to the sum of the good of individuals but to those goods which, in a certain community, serve the interest of people generally in a conflict-free, nonexclusive, and non-excludable way". As the author continues to argue (37-40), individual rights do secure a large part of this common good or public interest. Pertinent to the present case, the author agues at 39: "Rights such as freedom of marriage and freedom of occupation are most like freedom of contract. They create an environment in which careers are freely chosen and family ties freely undertaken. [...] Freedom of contract, freedom of occupation, and freedom of marriage, by affecting the mode of entry into various relationships and enterprises, affect the nature, content, and significance of those enterprises. And their impact is not confined to those who make use of them. They affect everyone in the community where they prevail".

117 This approach is mirrored in a pre-constitutional case of Atlas Organic Fertilizers (Pty) Ltd v Pikkewyn Ghwano (Pty) Ltd 19812 SA 173 (T) 188, where the court stated that the determination and application of the boni mores criterion requires that the "interests of the competing parties have to be weighed, bearing in mind also the interests of society, the public weal" (Emphasis added). The approach treats the public interest as an invisible element that swings both ways depending on the finding of the court in weighing up the rivaling interests of the parties. The approach may result in certain interests that are not connected to the litigants being overlooked in the weighing-up process. 
entity. This argument shows just how expansive corporate tendencies can be and why the public interest in the outcome of the dispute should be factored into the equation before it reaches its answer. If the (constitutionally construed) public interest only ever confirms a foregone conclusion, industry developments caused and steered by judicial ${ }^{118}$ or legislative ${ }^{119}$ pronouncement will likely continue on a separate trajectory to those routes available to society that are arguably more conducive to actualising the constitutional vision. This would allow rights-talk to overshadow collective and common interests, permitting economic power to further concentrate, and could lead to a substantial derogation of the public benefits that are said to flow from free competition. The court's partial awareness of this is evident, ${ }^{120}$ but the impact beyond the two rights (sections 22 and 25 of the Constitution) is never investigated, and the two iterations of liberty are left to compete for positive moral valence.

The apparent conflict between the two rights was resolved by the conclusion that the property right did not prohibit the conduct of which the applicants complained and that there was no salient reason to develop the common law right to that extent. ${ }^{121}$ While we agree with this conclusion, we lament

118 One example of this is Phumelela, where the court guided the development of the bet-making industry by determining the sway of the public boni mores and the numerous public interests involved.

119 South African Diamond Producers Organisation v Minister of Minerals and Energy 20176 SA 331 (CC), where legislation outlawed existing practices in the diamond selling business, effectively rendering unlawful an entire profession.

120 Discovery paras 90-91.

121 Underkuffler Idea of Property 64-84 proposes a classification of legal disputes that categorises conflicts between rights and the public interest. On her model, courts should inquire into the underlying value that the right and interest serve respectively: if the ostensibly competing legal constructs are iterations of different and competing values, then the conflict is genuine and should be resolved according to the political content given to each, but if the right and public interest are both iterations of the same underlying value, then the conflict is properly classified as a delimitation of the value's scope and ambit, thus a definitional exercise rather than a resolutive one. Underkuffler explains that when the competing interests - whether rights or something lower on the conventional hierarchy of legal positions - are properly identified as two iterations of the same interest, the conflict immediately dissolves into a delimitation exercise, as it would be illogical for an interest to oppose its own full realisation. This means that weighing is not on the cards because the court is seized with a definitional exercise. Because the right to freedom of trade is clearly premised on the value of individual liberty in the liberal legal tradition, the apparent conflict with the right to prevent unlawful competition, which is also an expression of the value of liberty in the economic context, is in fact correctly construed as a delineation exercise of the underlying value and interest. This is ultimately the finding of the Discovery court: that there is no conflict, as the liberty interest does not generate a right in positive law to prevent third parties who are not direct competitors from using proprietary information generated by a business system - which information is not owned by the applicant - in operating a complementary business that encourages existing customers of the first business to remain so. There could 
the distortion of constitutional values and methodology that accompanies it. Classifying the unlawful competition dispute as a definitional exercise rather than a balancing exercise would have alleviated much of the self-inflicted cognitive obfuscation. This would have allowed the court to discover the extent of the value of individual liberty in the context of horizontal application and clarified the relationship between the two distinct constructions of this value.

In sum, then, the Discovery court made all the right noises, referring to the only Constitutional Court precedent on point, and was sure to quote a few pertinent paragraphs to situate the dispute in the proper context. Unfortunately, the court gave no indication of the basis of its reasoning or how it arrived at the conclusion that it did, with which we broadly concur, other than by weighing all relevant factors to determine wrongfulness. Although the court refers to Laugh It Off Concourt and Phumelela, both of which identified section 39(2) as the appropriate entry point for constitutional balancing, the Discovery court failed to invoke this provision as its basis, with the resulting failure to incorporate the spirit, purport and objects of the Bill of Rights when applying and considering the development of the common law of unlawful competition. The court appeared to weigh against each other factors grounded in the competing constitutional rights without any methodological anchor or context, map or signposts to chart its journey.

It may seem strange to suggest that the court needed a constitutional basis to determine an element of the common law of delict, but this is exactly the contention. It is precisely because the common law has always done legal reasoning in a certain way, being driven by an internal logic and ethic some of which is perfectly compatible with constitutional counterparts, some of it less so - that an explicit constitutional basis is needed to ground and direct the normative aspects of reasoning. This is no more than what section 39(2) of the Constitution requires:

When interpreting any legislation, and when developing the common law or customary law, every court, tribunal or forum must promote the spirit, purport and objects of the Bill of Rights. ${ }^{122}$

Plainly, courts have no discretion in whether to consult the Bill of Rights when going about the judicial business of interpreting and applying the law,

be no conflict between these two rights because they were both based on the same interest, and what was framed as a conflict was no more than a misleading framing 
as well as when developing the common law, as the court was implored to do by the applicants.

\section{Conclusion}

The decision happens to have the effect, in our view, of entrenching the constitutional concept of individual liberty rendered in a more communal ideological context than liberal legalism typically yields, and certainly more than is evident in inherited private law regimes. Yet the court may as well have arrived at the outcome by random chance for all the clarity it lends future courts. One is left to conclude that the court did implicitly steer itself down the section $39(2)$ route in the unlawful competition analysis but stopped short of proclaiming it as such. Unfortunately, as argued above, the greater constitutional context is largely ignored and the ambit of the relevant public interest - rendered as the public boni mores - is condensed to the reasons underlying the section 22 right. The constrained manner in which the court construes the value of individual liberty betrays an unwillingness to give the value constitutionally-inspired content. As a result, future courts are left to wonder whether the private law route of delictual liability is open to constitutional influence in any meaningful way, as this judgment can be read to support the idea that the Constitution should be consulted only as a failsafe, to make sure that private law is not doing anything untoward (which it never is, when invoked to validate a foregone legal conclusion).

By failing to root its methodology in any constitutional provision, the court makes it unnecessarily difficult to reverse-engineer the decision and replicate it in future cases, where only the most discerning future courts will be able to trace remnants of section 39(2). Moreover, the court simply invokes constitutional values as if they have self-evident meaning in all contexts, leaving spectators to wonder which variant of the numerous possibilities it has tacitly elected. At no point does the court proffer any constitutional reference point for its reasoning, and it is not clear why no other values or provisions in the Bill of Rights feature in any form.

The court carves out the value of liberty from private law principles that do not necessarily relate to a democratic conception of that right and value aside from the dimensions captured by the section 22 right. ${ }^{123}$ This was an exercise of delimiting the common law right, ${ }^{124}$ stopping short of finding a

123 The s 25 right could also be seen as an iteration of liberty in the traditional liberal tradition, protecting individuals (and juristic persons by extension) against state incursion. This is one function of a property clause.

124 Van der Walt 2014 Journal of Law, Property, and Society 51: "[D]etermining the limits of the relevant property right involves a demarcation exercise and not a balancing of 
need to develop the law in this area, in which either the property right or the right to freedom of trade may be limited in accordance with section 36 of the Constitution. ${ }^{125}$ We hold the opinion that this does a disservice to the project of the constitutional transformation of private law sources, both in the present instance and in future cases where courts are likely to follow this approach of apparent balancing without first determining whether the delimitation of the underlying values may obviate the need for this. Reaching the correct outcome in this case does not justify concealing the route that led to it.

\section{Bibliography}

\section{Literature}

Currie and De Waal Bill of Rights Handbook

Currie I and De Waal J The Bill of Rights Handbook $6^{\text {th }}$ ed (Juta Cape Town 2013)

\section{Danay and Foster 2006 SAJHR}

Danay RJ and Foster J "The Sins of the Media: The SABC Decision and the Erosion of Free Press Rights" 2006 SAJHR 563-596

Davis 2012 SALJ

Davis DM "How Many Positivist Legal Philosophers Can be Made to Dance on the Head of a Pin? A Reply to Professor Fagan" 2012 SALJ 59-72

Davis 2013 SALJ

Davis DM "The Importance of Reading - A Rebutter to the Jurisprudence of Anton Fagan" 2013 SALJ 52-59

Du Bois 2012 SA Merc LJ

Du Bois M "Intellectual Property as a Constitutional Property Right: The South African Approach" 2012 SA Merc LJ 177-193

the relevant rights - the point is not to ascertain (in every case, based on the facts) which right weighs heavier but to determine (abstractly, as a matter of definition) where the limit of property rights inevitably has to be drawn to secure these nonproperty rights."

125 Although there is some debate over whether the steps of finding and applying the common law and developing the common law are notionally distinct (see Fagan 2010 SALJ; Davis 2012 SALJ; Fagan 2012 SALJ; Davis 2013 SALJ), the affirmative view is sometimes adopted by conservative legal scholars to argue that the Constitution should, on its own terms, have no role to play when the common law is not developed, but merely applied to the facts at hand. This line of argument has the primary effect of insulating the common law from constitutional influence, continuing the private law business-as-usual approach in the commercial sector, subject only to the common law notions of justice. 
Dworkin Law's Empire

Dworkin R Law's Empire (Belnap Press Cambridge 1986)

Fagan 2010 SALJ

Fagan A "The Secondary Role of the Spirit, Purport and Objects of the Bill of Rights in the Common Law's Development" 2010 SALJ 611-627

Fagan 2012 SALJ

Fagan A "A Straw Man, Three Red Herrings, and a Closet Rule-Worshipper - A Rejoinder to Davis JP" 2012 SALJ 788-798

IIIsley 2006 SAJHR

Illsley $T$ "How to Tell a Take-Off from a Rip-Off: Trade Mark Parody and Freedom of Expression in South Africa" 2006 SAJHR 119-125

Mills 2014 PELJ

Mills $L$ "The Regulations Relating to Foodstuffs for Infants and Young Children (R991): A Formula for the Promotion of Breastfeeding or Censorship of Commercial Speech?" 2014 PELJ 252-295

Neethling 2008 SA Merc LJ

Neethling $\mathrm{J}$ "The Law of Unlawful Competition (Misappropriation of a Rival's Product) and its Constitutional Compatibility: Phumelela Gaming and Leisure Ltd v Gründlingh" 2008 SA Merc LJ 414-421

Neethling Unlawful Competition

Neethling J Unlawful Competition $2^{\text {nd }}$ ed (LexisNexis Durban 2008)

Nel 2004 CILSA

Nel S "Freedom of Commercial Speech: Evaluating the Ban on Advertising of Legal Products such as Tobacco" 2004 CILSA 65-83

Raz Ethics in the Public Domain

Raz J Ethics in the Public Domain: Essays in the Morality of Law and Politics (Oxford University Press New York 1994)

Underkuffler Idea of Property

Underkuffler L The Idea of Property: Its Meaning and Power (Oxford University Press New York 2003)

Van der Walt 2014 Journal of Law, Property, and Society

Van der Walt AJ "The Modest Systemic Status of Property Rights" 2014 Journal of Law, Property, and Society 15-106

\section{Case law}

Abbott Laboratories v UAP Crop Care (Pty) Ltd 19993 SA 624 (C) 
Abdulhay M Mayet Group (Pty) Ltd v Renasa Insurance Co Ltd 19994 SA 1039 (TPD)

Affordable Medicines Trust v Minister of Health 20063 SA 247 (CC)

Atlas Organic Fertilizers (Pty) Ltd v Pikkewyn Ghwano (Pty) Ltd 19812 SA $173(\mathrm{~T})$

Barkhuizen v Napier 20075 SA 323 (CC)

Basson v Chilwan 19933 SA 742 (A)

British American Tobacco South Africa (Pty) Ltd v Minister of Health 20123 All SA 593 (SCA)

City of Cape Town v Ad Outpost (Pty) Ltd 20002 SA 733 (C)

Commercial Auto Glass (Pty) Ltd $v$ Bayerische Motoren Werke AktienGesellschaft 20076 SA 637 (SCA)

Country Cloud Trading CC $v$ MEC, Department of Infrastructure Development, Gauteng 20151 SA 1 (CC)

CTP Ltd v Argus Holdings Ltd 19954 SA 774 (A)

De Reuck v Director of Public Prosecutions (Witwatersrand Local Division) 20041 SA 406 (CC)

Discovery Ltd v Liberty Group Ltd 20204 SA 160 (GJ)

Giddey v JC Barnard 20075 SA 525 (CC)

Independent Outdoor Media v City of Cape Town 20132 All SA 679 (SCA)

Investigating Directorate: Serious Economic Offences v Hyundai Motor Distributors (Pty) Ltd In re: Hyundai Motor Distributors (Pty) Ltd v Smit 2001 1 SA 545 (CC)

Islamic Unity Convention v Independent Broadcasting Authority 20024 SA 294 (CC)

Khumalo v Holomisa 20025 SA 401 (CC)

Laugh It Off Promotions CC v South African Breweries International 20044 All SA 151 (SCA)

Laugh It Off Promotions CC $v$ South African Breweries International (Finance) BV t/a Sabmark International 20061 SA 144 (CC)

Loureiro v Mvula Quality Protection (Pty) Ltd 20143 SA 394 (CC) 
Magna Alloys \& Research (SA) (Pty) Ltd v Ellis 19844 SA 874 (A)

Masstores (Pty) Limited v Pick n Pay Retailers (Pty) Limited 20171 SA 613 (CC)

Midi Television (Pty) Ltd v Director of Public Prosecutions (Western Cape) 20073 All SA 318 (SCA)

Motherland Design Agency (Pty) Ltd v Whitefernfranc (Pty) Ltd 2020 ZALCJHB 145 (31 August 2020)

North Central Local Council and South Central Local Council v Roundabout Outdoor (Pty) Ltd 20022 SA 625 (D)

Paulsen v Slip Knot Investments 777 (Pty) Limited 20153 SA 479 (CC)

Pharmaceutical Manufacturers Association of South Africa: In re Ex Parte President of the Republic of South Africa 20002 SA 674 (CC)

Phumelela Gaming and Leisure Limited v Gründlingh 20076 SA 350 (CC)

Prestonettes Inc v Coty 1924263 US 359

Reddy v Siemens Telecommunications (Pty) Ltd 20072 SA 486 (SCA)

$S$ v Mamabolo 20013 SA 409 (CC)

South African Broadcasting Corporation Ltd v Downer 20071 All SA 384 (SCA)

South African Broadcasting Corporation Ltd $v$ National Director of Public Prosecutions 20071 SA 523 (CC)

South African Diamond Producers Organisation v Minister of Minerals and Energy 20176 SA 331 (CC)

Strike Productions (Pty) Ltd v Bon View Trading 131 (Pty) Ltd 2011 ZAGPJHC 1 (20 January 2011)

Verimark (Pty) Ltd $v$ Bayerische Motoren Werke AktienGesellschaft: Bayerische Motoren Werke AktienGesellschaft v Verimark (Pty) Ltd 20076 SA 263 (SCA)

\section{Legislation}

Constitution of the Republic of South Africa, 1996

Trade Marks Act 194 of 1993 


\section{List of Abbreviations}

CILSA

PELJ

SAJHR

SALJ

SA Merc LJ
Comparative and International Law Journal of Southern Africa

Potchefstroom Electronic Law Journal South African Journal on Human Rights South African Law Journal

South African Mercantile Law Journal 